\title{
PENEGAKAN HUKUM ATAS KETIDAKPATUHAN PERUSAHAAN DALAM MENERAPKAN SISTEM MANAJEMEN KESELAMATAN DAN KESEHATAN KERJA
}

\author{
Fadli Akbar, Budi Santoso, Siti Hamidah \\ Magister Ilmu Hukum, Program Pasca Sarjana Universitas Brawijaya \\ Jl. MT. Haryono No 169 Malang, Jawa Timur, Indonesia \\ Email: gendaz1995@gmail.com
}

\begin{abstract}
PT. Karebet Mas Indonesia Branch of Muara Jawa has mentioned the existence of facilities for personal protective equipment against workers/laborers, but in the implementation of PT. Karebet Mas Indonesia does not all carry out the contents of the agreement and only partially runs for approximately 2 years. The formulation of the problem taken in this reserch is what the obstacles faced by the Manpower and Transmigration Agency of East Kalimantan Province are in enforcing sanctions for companies that do not comply with the occupational health and safety management system. This type of research is empirical juridical with a sociological juridical research approach. The conclusion of this research is the obstacle of the Manpower and Transmigration Office in enforcing the law because the human resources and budgetary funds that do not support and in finding violations of the law on the Manpower and Transmigration Office of East Kalimantan Province are passive.
\end{abstract}

Keywords: Occupational Health and Safety Management System, Supervision, Workers/Laborers.

\begin{abstract}
Abstrak
PT.Karebet Mas Indonesia Cabang Muara Jawa telah menyebutkan adanya fasilitas alat pelindung diri terhadap para pekerja/buruh, tetapi pada pelaksanaanya PT. Karebet Mas Indonesia tidak semua menjalankan isi dari perjanjian tersebut dan hanya menjalankan sebagian selama kurang lebih 2 tahun. Rumusan masalah yang di ambil dalam penelitian ini adalah apa hambatan yang di alamai oleh Dinas Ketenagakerjaan dan Transmigrasi Provinsi Kalimantan Timur dalam melakukan penegakan hukum pemberian sanksi bagi perusahaan yang tidak mematuhi sistem manajemen keselamatan dan kesehatan kerja. Jenis penelitian ini adalah yuridis empiris dengan pendekatan penelitian yuridis sosiologis. Kesimpulan penelitian ini adalah hambatan Dinas Ketenagakerjaan dan Transmigrasi dalam melakukan penegakan hukum ialah karena faktor sumber daya manusia dan anggaran dana yang tidak menunjang serta dalam menemukan pelanggaran hukum Dinas Ketenagakerjaan dan Transmigrasi Provinsi Kalimantan Timur bersifat pasif.
\end{abstract}

Kata Kunci : Sistem Manajemen Keselamatan dan Kesehatan Kerja, Pengawasan, Pekerja/Buruh. 


\section{A. PENDAHULUAN}

Tenaga kerja merupakan penduduk yang berada dalam usia kerja. Menurut UndangUndang Nomor 13 Tahun 2003 tentang Ketenagakerjaan Pasal 1 ayat 2 disebutkan bahwa tenaga kerja adalah setiap orang yang mampu melakukan perkerjaan guna menghasilkan barang atau jasa baik untuk memenuhi kebutuhan sendiri maupun untuk kebutuhan masyarakat. Dalam ketenagakerjaan pasti terdapat adanya perlindungan terhadap para pekerja untuk keamanan, kesehatan, dan keselamatan kerja yang biasa disingkat (K-3) . Upaya ini diberlakukan agar para tenaga kerja mendapatkan perlindungan terhadap suatu bidang pekerjaan yang dilakukannya dan meminimalis terhadap resiko para tenaga kerja.

Motivasi utama dalam melaksanakan keselamatan dan kesehatan kerja adalah untuk mencegah kecelakaan kerja dan penyakit yang ditimbulkan oleh pekerjaan. Oleh karena itu perlu melihat penyebab dan dampak yang ditimbulkannya. ${ }^{1}$ Dalam bidang ketenagakerjaan perlu adanya kehati-hatian dalam menjalankannya agar dapat meminimalisir terhadap bahaya dalam keselamatan kerja.

Kecelakaan kerja tidak saja menimbulkan korban jiwa maupun kerugian materi bagi pekerja dan pengusaha, tetapi juga dapat mengganggu proses produksi secara menyeluruh, merusak lingkungan yang pada akhirnya akan berdampak pada masyarakat luas ${ }^{2}$.Berbagai macam upaya untuk melaksanakan program Keamanan, Kesehatan, dan Keselamatan Kerja (K-3) di suatu perusahaan salah satunya adalah Alat Pelindung Diri (APD). Program ini biasa telah di cantumkan di dalam kontrak pekerja dengan pengusaha yang dimana pengusaha wajib untuk memberi perlindungan bagi para pekerjanya sesuai dengan Pasal 86 ayat 1 UndangUndang Nomor 13 Tahun 2003 tentang Ketenagakeraan yang berbunyi "Setiap pekerja/buruh mempunyai hak untuk memperoleh perlindungan atas: 1. Keselamatan dan kesehatan kerja; 2. Moral dan kesusilaan; 3. Perlakuan yang sesuai dengan harkat dan martabat manusia seta nilai-nilai agama. Selain itu Pasal 87 ayat 1 Undang-Undang Nomor 13 Tahun 2003 tentang Ketenagakerjaan yang menyebutkan bahwa "Setiap perusahaan wajib menerapkan sistem manajemen keselamatan dan kesehatan kerja yang terintergrasi dengan sistem manajemen perusahaan. Aturan ini akan terlaksana jika dari sistem pengawasan berjalan efektif dan kesadaran dari pihak perusahaan dalam menjalaninya.

Perlu adanya tingkat pengawasan yang tinggi untuk melakasanakan program keamanan, kesehatan, dan keselamatan kerja (K-3) dari pemerintah agar pengawasan berjalan sebagai mana mestinya dan tidak terjadi penyimpangan-penyimpangan dari kedua belah pihak antara pihak pengusaha dan pihak pekerja/buruh yang dapat merugikan. Tetapi dalam penerapannya pasti terdapat cela hukum yang membuat sebuah kebiasaaan terus menerus sehingga kesadaran akan hukum hilang dan menimbulkan dampak yang merugikan. Jika dalam

1 ILO (International Labour Organization), 2013, Keselamatan dan Kesehatan Kerja ditempat Kerja, Modul 5, Jakarta, Halaman 3.

2 http://budayasafety.com/2013/10/artikel-tentang-keselamatan-kerja-k3.html diakses pada tanggal 24/01/2017 pukul 13.20 WITA 
pelaksanaan sistem manajemen keselamatan dan kesehatan kerja tidak berjalan sebagaimana mestinya sesuai peraturan perundang-undangan yang berlaku maka suatu perusahaan tersebut dapat dikenakan sanksi administratif sesuai dengan isi dari Pasal 190 Undang-Undang Nomor 13 Tahun 2003 Tentang Ketenagakerjaan yang menjelaskan :

(1) Menteri atau pejabat yang ditunjuk mengenakan sanksi administratif atas pelanggaran ketentuan-ketentuan sebagaimana diatur dalam Pasal 5, Pasal 6, Pasal 15, Pasal 25, Pasal 38 ayat (2), Pasal 45 ayat (1), Pasal 47 ayat (1), Pasal 48, Pasal 87, Pasal 106, Pasal 126 ayat (3), dan Pasal 160 ayat (1) dan ayat (2) undang-undang ini serta peraturan pelaksanaannya. (2) Sanksi administratif sebagaimana dimaksud dalam ayat (1) berupa:

a. teguran;

b. peringatan tertulis;

c. pembatasan kegiatan usaha;

d. pembekuan kegiatan usaha;

e. pembatalan persetujuan;

f. pembatalan pendaftaran;

g. penghentian sementara sebagian atau seluruh alat produksi;

h. pencabutan ijin.

(3) Ketentuan mengenai sanksi administratif sebagaimana dimaksud dalam ayat (1) dan ayat (2) diatur lebih lanjut oleh Menteri.

Di perusahaan PT. Karebet Mas Indonesia Cabang Muara Jawa, merupakan salah satu perusahaan yang berada di Kabupaten Kutai-Kartenegara di Jalan Mutiara 34 Sindang Jaya Rt.XI Kelurahan Muara Jawa Tengah, Kecamatan Muara Jawa, Kabupaten Kutai Kartanegara. Merupakan perusahaan yang bergerak dibidang "Minyak bumi dan Gas alam" yang merupakan anak cabang dari perusahaan PT. Karebet Mas Group. Perusahaan PT. Karebet Mas Indonesia mempekerjakan buruh/pekerja dengan rata-rata jam kerja 9 jam dengan jumlah pegawai sebanyak 31 orang. Dalam kontrak pernjanjian kerja Perusahaan PT. Karebet Mas Indoensia telah menyebutkan adanya fasilitas Alat Pelindung Diri (APD) terhadap para buruh/pekerja.

Alat Pelindung Diri merupakan salah satu bagian dari pelaksanaan upaya keamanan, kesehatan, dan keselamatan kerja (K-3) dalam suatu perusahaan yang wajib hukumnya untuk terpenuhi agar para pekerja/buruh dapat terhindar dari adanya dampak resiko dalam suatu pekerjaan yang dijalani serta dapat merasakan rasa nyaman dalam melakukan pekerjaan tersebut. Tetapi, selama kurang lebih 2 tahun kurun waktu pihak perusahaan PT. Karebet Mas Indonesia hanya menjalankan sebagian isi dari perjanjian kontrak tersebut yaitu Alat Pelindung Diri jas hujan dan pakaian seragam kerja yang tidak dijalankan karena adanya suatu alasan berupa berkurangnya pendapatan pihak perusahaan. Penerapan keamanan, 
kesehatan, dan keselamatan kerja (K-3) di perusahaan PT. Karebet Mas Indonesia tidak berjalan sesuai dengan peraturan perundang-undangan yang berlaku. ${ }^{3}$

Dari penjelasan latar belakang masalah tersebut, penulis tertarik melakukan penelitian terhadap penegakan hukum atas hah-hak buruh/pekerja terutama mengenai Alat Pelindung Diri (APD) di perusahaan PT. Karebet Mas Indonesia. Dalam hal ini apakah dari pihak perusahaan menjalankan isi dari perjanjian/kontrak kerja secara baik sesuai dengan perundang-undangan yang berlaku, dan apakah bentuk pengawasan dari pemerintah terhadap isi perjanjian kontrak dalam suatu perusahaan sudah efektif sesuai aturan yang berlaku saat ini.

\section{B. RUMUSAN PERMASALAHAN}

Berdasarkan latar belakang masalah yang telah diuraikan dapat diformulasikan sebuah rumusan masalah yaitu: Apa hambatan yang di alami oleh Dinas Ketenagakerjaan dan Transmigrasi Provinsi Kalimantan Timur dalam melakukan penegakan hukum pemberian sanksi bagi perusahaan yang tidak mematuhi sistem manajemen keselamatan dan kesehatan kerja?

\section{METODE PENELITIAN}

Jenis penelitian ini adalah yuridis empiris dengan pendekatan penelitian yuridis sosiologis. Lokasi penelitian ini ialah Dinas Ketenagakerjaan dan Transmigrasi Provinsi Kalimantan Timur dan PT. Karebet Mas Indonesia Cabang Muara Jawa Kutai Kartanegara. Penelitian ini menggunakan populasi dan sampel dengan populasi dari pekerja/buruh PT. Karebet Mas Indonesia dan pejabat pemerintah yang bekerja di Dinas Ketenagakerjaan dan Transmigrasi Provinsi Kalimantan Timur. Sumber data penelitian ini terbagi atas data primer dan data sekunder. Teknik pengumpulan data penelitian ini terdiri dari studi lapangan, studi kepustakaan, dan studi dokumen. Analisis data yang digunakan adalah deskriftif - kualitatif.

\section{PEMBAHASAN}

1. Hambatan Dinas Ketenagakerjaan dan Transmigrasi Provinsi Kalimantan Timur dalam melakukan penegakan hukum pemberian sanksi bagi perusahaan yang tidak mematuhi sistem manajemen keselamatan dan kesehatan kerja

Perlindungan terhadap para pekerja/buruh sangat penting sehingga telah diatur didalam Pasal 86 Undang-Undang Nomor 13 Tahun 2003 Tentang Ketenagakerjaan yang menyebutkan bahwa: 2017.

${ }^{3}$ Pra survey, wawancara dengan saudari Anggita Monika selaku admin HCGS pada tanggal 2 Februari 
(1)Setiap pekerja/buruh mempunyai hak untuk memperoleh perlindungan atas: a. keselamatan dan kesehatan kerja; b. moral dan kesusilaan; dan c. perlakuan yang sesuai dengan harkat dan martabat manusia serta nilai-nilai agama.

(2) Untuk melindungi keselamatan pekerja/buruh guna mewujudkan produktivitas kerja yang optimal diselenggarakan upaya keselamatan dan kesehatan kerja.

(3) Perlindungan sebagaimana dimaksud dalam ayat (1) dan ayat (2) dilaksanakan sesuai dengan peraturan perundang- undangan yang berlaku.

Pemerintah telah mangaturnya karena untuk menjaga kesejahteraan pekerja/buruh dengan pengusaha agar terhindar dari penyalahgunaan wewenang dari pihak atasan perusahaan. Resiko dari setiap pekerjaan cukup beragam bergantung dari tingkat dan bidang pekerjaan setiap perusahaan, upaya keselamatan dan kesehatan kerja cukup membantu untuk melindungi para pekerja/buruh dalam menjalankan suatu pekerjaan yang dilakukan dari upaya dari pemerintah ini para pekerja/buruh dapat meminimalis terhadap adanya resiko kecelakaan kerja.

Dalam menjalankan program keselamatan dan kesehatan kerja di suatu perusahaan telah diatur didalam Pasal 87 Undang-Undang Nomor 13 Tahun 2003 Tentang Ketenagakerjaan yang menjelaskan bahwa "(1) Setiap perusahaan wajib menerapkan sistem manajemen keselamatan dan kesehatan kerja yang terintegrasi dengan sistem manajemen perusahaan. (2) Ketentuan mengenai penerapan sistem manajemen keselamatan dan kesehatan kerja sebagaimana dimaksud dalam ayat (1) diatur dengan Peraturan Pemerintah".

Atas dasar regulasi tersebut setiap perusahaan menerapkan sistem manajemen keselamatan dan kesehatan kerja yang terintegrasi dengan sistem manajemen perusahaan yang dalam artian dalam setiap perusahaan wajib melakukanya dan menyesuaikan dengan peraturan perundang-undangan yang berlaku. Dalam pelaksanaan penerapan sistem manajemen keselamatan dan kesehatan kerja telah diatur di dalam Peraturan Pemerintah Nomor 50 Tahun 2012 Tentang Penerapan Sistem Manajemen Keselamatan dan Kesehatan Kerja.

Perusahaan wajib mengikuti Peraturan yang tertuang dalam Peraturan Pemerintah Nomor 50 Tahun 2012 Tentang Penerapan Sistem Manajemen Keselamatan dan Kesehatan Kerja karena merupakan pedoman untuk perusahaan dalam menajalani program keselamatan dan kesehatan kerja. Dalam Pasal 3 Peraturan Pemerintah Nomor 50 Tahun 2012 Tentang Penerapan Sistem Manajemen Keselamatan dan Kesehatan Kerja menyebutkan bahwa "(1) Penerapan SMK3 dilakukan berdasarkan kebijakan nasional tentang SMK3. (2) Kebijakan nasional tentang SMK3 sebagaimana dimaksud pada ayat (1) tertuang dalam Lampiran I, Lampiran II, dan Lampiran III sebagai bagian yang tidak terpisahkan dari Peraturan Pemerintah ini". 
Secara substansi hukum pemerintah telah mengatur tentang keselamatan dan kesehatan kerja, dan perusahaan wajib mengikuti dan menyesuaikan didalam peraturan perusahaan agar dapat menjamin keselamatan para pekerja/buruh didalam menjalankan pekerjaan dan meminimalis adanya dampak bahaya terhadap pekerja/buruh.

Perusahaan PT. Karebet Mas secara formal telah mengikuti peraturan perundang-undangan yang berlaku. Perlindungan yang dilakukan terhadap para pekerja/buruh din perusahaan PT. Karebet Mas Indonesia telah dicantumkan didalam perjanjian kerja perusahaan. Didalam perjanjian kerja perusahaan PT. Karebet Mas Indonesia Pasal 11 tentang Perlengkapan Keselamatan Kerja / Alat Pelindung Diri menjelaskan bahwa PIHAK PERTAMA menyediakan perlengkapan keselamatan kerja yang harus dipakai oleh PIHAK KEDUA pada saat melaksankan pekerjaan sesuai dengan standar masa pakai APD PT. Karebet Mas Indonesia, Adapun standard pemberian APD sesuai masa pakai sebagai berikut :

a. Pakai Seragam kerja $=6$ (Enam) Stell/ 3 tahun ( Ket : Diberikan pertahun 2 (dua) Stell/ 1 tahun).

b. Sepatu Kerja / Safety Shoes $=3$ (Tiga) pasang / 3 tahun ( Ket : Diberikan Pertahun 1 (satu) Pasang / 1 tahun).

c. Kacamata / Safety Goggles = 3 (Tiga) pasang / 3 tahun ( Ket : Diberikan Pertahun 1 (satu) Buah / 1 tahun ).

d. Helm Safety $=3$ (Tiga) pasang / 3 tahun ( Ket : Diberikan Pertahun 1 (satu) Buah / 1 tahun ).

e. Jas Hujan = 3 (Tiga) pasang / 3 tahun ( Ket : Diberikan Pertahun 1 (satu) Buah / 1 tahun ).

f. Pelindung telinga / Ear Plug = 12 (Dua Belas) buah / 3 tahun ( Ket : Diberikan Pertahun 1 (satu) Buah / 3 Bulan ).

g. Sarung tangan / Hand Gloves = disesuaikan dengan kebutuhan

Jika terjadi APD yang diberikan ( Hilang, Rusak tidak wajar ) sebelum waktu yang telah ditentukan diatas, maka karyawan WAJIB Mengganti APD dengan spesifikasi standart seperti yang telah diberikan oleh perusahaan. Selain itu sebagai karyawan wajib untuk menggunakan dan merawat semua alat keselamatan dan fasilitas pendukung yang disediakan oleh perusahaan untuk mencegah terjadinya kerusakaan atau kerugian yang disebabkan oleh kelalaian karyawan. Pelanggaran terhadap ketentuan ini dapat diberikan sanksi sesuai peraturan yang berlaku. ${ }^{4}$

Perusahaan PT. Karebet Mas Indonesia didalam perjanjian kerjanya telah mengikuti peraturan perundang-undangan yang berlaku yaitu telah menuangkan fasilitas Alat Pelindung Diri terhadap para pekerja/buruh. Tetapi dalam pelaksanaanya berdasarkan informasi yang penulis dapatkan dari pekerja/buruh di PT.

\footnotetext{
${ }^{4}$ Perjanjian Kerja Waktu Tertentu Perusahaan PT. Karebet Mas Indonesia.
} 
Karebet Mas Indonesia perusahaan PT. Karebet Mas Indonesia dalam kurun 2 tahun terakhir tidak menjalankan isi dari pasal 11 Perjanjian kerja dengan sepenuhnhya.

Menurut Bapak Ferdiansyah ada beberapa Alat Pelindung Diri yang tidak dipenuhi oleh perusahaan PT. Karebet Mas Indonesia, Pertama PT. Karebet Mas Indonesia tidak pernah memberikan Jas Hujan yang tercantum dalam isi perjanjian kerja selama 2 tahun terakhir . Kedua, Alat Pelindung Diri yang tidak diberikan oleh perusahaan adalah Pakaian Seragam Kerja yang tidak pernah diberikan oleh perusahaan PT. Karebet Mas Indonesia. ${ }^{5}$ Di lokasi yang berbeda penulis melakukan wawancara dengan Saudari Anggita Monika yang mengatakan bahwa dari pihak perusahaan PT. Karebet Mas Indonesia telah mengajukan pengadaan barang terhadap Alat Pelindung Diri yang diperlukan kepada Head Office PT. Karebet Mas Group tetapi tidak mendapatkan hasil yang positif. Pihak Perusahaan memberitahukan kepada para pekerja/buruh bahwa perusahaan PT. Karebet Mas Group sedang mengalami defisit financial. ${ }^{6}$

Menurut Bapak Edy Prasetya kendala yang dihadapi oleh pekerja/buruh jika tidak memiliki Alat Pelindung Diri dengan lengkap ialah menggunakan Alat Pelindung Diri yang lama yang sudah melebihi masa kadaluarsa. Sehingga para pekerja/buruh yang ditemui tidak menggunakan Alat Pelindung Diri dengan terpaksa melakukan pekerjaan tersebut. Hal ini para pekerja/buruh merasa dirugikan dan tidak mendapatkan haknya dalam melakukan pekerjaan. ${ }^{7}$

Dalam hal ini para pekerja/buruh merasa memaklumi dengan pernyataan yang dikeluarkan oleh pihak atasan PT. Karebet Mas Group sehingga menimbulkan suatu kebudayaan yang tidak mentaati Peratutran Pemerintah Nomor 50 Tahun 2012 tentang Penerapan Sistem Manajemen Keselamatan dan Kesehatan Kerja.

Saiful Anwar, pengawasan atau kontrol terhadap tindakan aparatur pemerintah diperlukan agar pelaksanaan tugas yang telah ditetapkan dapat mencapai tujuan dan terhindar dari penyimpangan-penyimpangan. ${ }^{8}$ Untuk menciptakan suatu efektivitas suatu peraturan perundang-undangan yang berlaku diperlukan adanya pengawasan dalam menjalankanya. Pada kasus ini yang mempunyai kewenangan untuk mengawasi kinerja dari suatu perusahaan yaitu Dinas Ketenagakerjaan dan Transmigrasi Provinsi Kalimantan Timur.

\footnotetext{
${ }^{5}$ Hasil wawancara langsung dengan Bapak Ferdiansyah Operator Truk dan Trailer pada tanggal 16 April 2019.

${ }^{6}$ Hasil wawancara langsung dengan Saudari Anggita Monika selaku Admin HCGS di PT.Karebet Mas Indonesia pada tanggal 16 April 2019.

7 Hasil wawancara dengan Bapak Edy Prasetya selaku Production Admin pada tanggal 16 April 2019.

8 Saiful Anwar, Op-Cit, Halaman 127
} 
Berdasarkan wawancara dengan Ibu Mariani pada tanggal 15 Januari 2019. Ibu Mariani menjelaskan kewenangan pengawasan yang tadinya berada di Kabupaten / Kota dialihkan ke pusat berdasarkan Pasal 15 ayat 1 dan 2 Undang-Undang Nomor 23 Tahun 2014 tentang Pemerintahan Daerah dalam pelaksanaanya sinergi antara Kabupaten / Kota dengan Provinsi. Pengawasan dari Pemerintah terhadap perusahaan-perusahaan dilakukan dalam kurun waktu setahun sekali akan tetapi tidak semua perusahaan dapat diawasi. Perusahaan di Provinsi Kalimantan Timur yang terdaftar hingga saat ini sebanyak kurang lebih 80.000 perusahaan kemungkinan yang bisa diawasi hanya sekitar 50\% dari seluruh perusahaan yang berada di Provinsi Kalimantan Timur. ${ }^{9}$

Adapun beberapa faktor kendala yang dihadapin dalam melakukan pengawasan oleh Dinas Ketenagakerjaan dan Transmigrasi Provinsi Kalimantan Timur :

a. Faktor Sumber Daya Manusia

Kendala Pemerintah yang pertama yaitu Jumlah pengawas yang berada di Provinsi Kalimantan Timur sebanyak 59 orang pengawas dan 12 orang diantaranya adalah pengawas spesialis. Dalam setiap pengawas dapat melakukan pengawasan sebanyak 5 perusahaan perbulan jadi pertahun pengawas dapat mengawasi perusahaan sebanyak 60 perusahaan pertahunya. Dari semua pengawas kira-kira pemerintah dapat mengawasi sebanyak kurang lebih 3.500 Perushaan yang berada di Provinsi Kalimantan Timur sesuai dengan standar pelayanan minimal. ${ }^{10}$ Dengan terbatasnya jumlah pegawai pengawas yang berada di Dinas Ketenagakerjaan dan Transmigrasi Provinsi Kalimantan Timur menurut penulis merupakan salah satu penghambat untuk dilakukannya pengawasan terhadap suatu perusahaan yang tidak mentaati peraturan perundang-undangan khususnya di PT.Karebet Mas Indonesia Cabang Muara Jawa sehingga untuk melakukan penegakan hukum tidak berjalan sebagai mestinya.

b. Faktor kurangnya anggaran dana

Kendala yang kedua adalah masalah dana penunjang untuk melakukan pengawasan tidak mencukupi. Dari anggaran yang tersedia kemungkinan hanya $50 \%$ saja yang bisa terpenuhi untuk menunjang setiap pengawas ke perusahaanperusahaan yang berada di Provinsi Kalimantan Timur. Pengawasan yang seharusnya terawasi secara menyeluruh kepada setiap perusahaan menjadi tidak terawasi dengan baik dan tidak semua perusahaan dapat di awasi oleh pemerintah,

\footnotetext{
${ }^{9}$ Hasil wawancara langsung dengan Ibu Mariani Selaku Kepala Seksi Keselamatan dan Keselamatan Kerja Dinas Ketenagakerjaan dan Transmigrasi Provinsi Kalimantan Timur, 15 Januari 2019.

10 Hasil wawancara dengan Ibu Mariani selaku Kepala Seksi Keselamatan dan Kesehatan Kerja di Dinas Ketenagakerjaan Provinsi Kalimatan Timur pada tanggal 15 Januari 2019.
} 
sehingga sering terjadi adanya pelanggaran-pelanggaran hukum terhadap para pekerja/buruh. ${ }^{11}$

Menurut Prayudi, dalam mencapai pelaksanaan pengawasan terhadap beberapa asas antara lain $:^{12}$

a. Asas tercapainya tujuan, ditujukan ke arah tercapainya tujuan yaitu dengan mengadakan perbaikan untuk menghindari penyimpangan-penyimpangan atau deviasi perencanaan. Pada kasus ini Dinas Ketenagakerjaan dan Transmigrasi Provinsi Kalimantan Timur tidak dapat memenuhi asas ini dikarenakan salah satu faktor sumber daya manusia yang terbatas akibatnya terjadi penyimpanganpenyimpangan dalam suatu perusahaan yang berada di Provisi Kalimantan Timur salah satunya yaitu PT.Karebet Mas Indonesia Cabang Muara Jawa.

b. Asas efisiensi, yaitu sedapat mungkin menghindari deviasi dari perencanaan sehingga tidak menimbulkan hal-hal lain diluar dugaan. Untuk mencapai titik efisiensi ini Dinas Ketenagakerjaan dan Transmigrasi Provinsi Kalimantan Timur sangat berat di karenakan faktor anggaran dana yang tidak memadai dalam melakukan pengawasan.

Pengawasan terhadap Perusahaan PT. Karebet Mas Indonesia terakhir diawasi pada tahun 2010 , sehingga dalam penerapan sistem keselamatan dan kesehatan kerja di PT. Karebet Mas Indonesia sering terjadi adanya pelanggaran-pelanggaran hukum yang tidak diketahui oleh Dinas Ketenagakerjaan. Ibu Mariani menjelaskan bahwa untuk melakukan pengawasan pemerintah dibantu dengan Panitia Pembina Keselamatan dan Kesehatan Kerja (P2K3) yang bertanggung jawab dibidang K3 disuatu perusahaan, dengan adanya $\mathrm{P} 2 \mathrm{~K} 3$ kami dapat berkoordinasi dengan perusahaan agar dapat mengecek bentuk sistem manajemen keselamatan dan kesehatan kerja dalam suatu perusahaan dan jika terjadi adanya pelanggaran di dalam perusahaan pekerja/buruh harus melaporkanya terlebih dahulu kepada petugas $\mathrm{P} 2 \mathrm{~K} 3$ kemudian dari pelaporan tersebut akan diproses dan dapat dilimpahkan ke Dinas Ketenagakerjaan jika perusahaan tidak melaksanakan sistem manajemen keselamatan dan kesehatan kerja dengan baik. Tetapi sampai saat ini dari informasi yang penulis dapat dari Dinas Ketenagakerjaan dan Transmigrasi Provinsi Kalimantan Timur untuk pelaporan dari pihak P2K3 ataupun pekerja/buruh di perusahaan PT. Karebet Mas Indonesia Cabang Muara Jawa yaitu nihil sehingga pihak Dinas Ketenagakerjaan dan Transmigrasi Provinsi Kalimantan Timur tidak mengetahui bentuk pelanggaranpelanggaran apa saja yang telah dilakukan di perusahan tersebut.

\footnotetext{
${ }^{11}$ Hasil wawancara dengan Ibu Mariani selaku Kepala Keksi Keselamatan dan Kesehatan Kerja di Dinas Ketenagakerjaan Provinsi Kalimatan Timur pada tanggal 15 Januari 2019.

12 Prayudi, Op-Cit ,hlm 83.
} 
Menurut Satjipto Raharjo penegakan hukum pada hakikatnya merupakan penegakan ide-ide atau konsep-konsep tentang keadilan, kebenaran, kemanfaatan sosial, dan sebagainya. Jadi Penegakan hukum merupakan usaha untuk mewujudkan ide dan konsep-konsep tadi menjadi kenyataan. Hakikatnya penegakan hukum mewujudkan nilai-nilai atau kaedah-kaedah yang memuat keadilan dan kebenaran, penegakan hukum bukan hanya menjadi tugas dari para penegak hukum yang sudah di kenal secara konvensional, tetapi menjadi tugas dari setiap orang. Meskipun demikian, dalam kaitannya dengan hukum publik pemerintahlah yang bertanggung jawab. Penegakan hukum dibedakan menjadi dua, yaitu : ${ }^{13}$

a. Ditinjau dari sudut subyeknya:

Dinas Ketenagakerjaan dan Transmigrasi Provinsi Kalimantan Timur sebagai alat pemerintah yang mempunyai kewenangan dalam melakukan pengawasan terhadap perusahaan-perusahaan yang tetapi terdapat beberapa kendala yang sering terjadi dalam penegakan hukum yaitu sumber daya manusianya yang terbatas dan keadaan dana anggaran yang tidak dapat menunjang kinerja Dinas Ketenagakerjaan dan Transmigrasi Provinsi Kalimantan Timur khususnya dibidang pengawas ketenagakerjaan. Sehingga pada kenyataannya yang didapati dilapangan kepastian dan jaminan terhadap penegakan hukum tidak berjalan sebagaimana seharusnya yang diinginkan.

b. Ditinjau dari sudut obyeknya, yaitu dari segi hukumnya:

Pada hakikatnya pelaksanaan SMK3 telah diatur didalam Peraturan Pemerintah Nomor 50 Tahun 2012 Tentang Sistem Manajemen Keselamatan dan Kesehatan Kerja terdapat didalam Lampiran I huruf C Pelaksanaan Rencanan K3 menyebutkan bahwa setiap perusahaan wajib mengalokasikan anggaran untuk keberlangsungan SMK3 pada suatu perusahaan. Hal ini dapat berjalan sebagai mana mestinya jika dari Dinas Ketenagakerjaan dan Transmigrasi Provinsi Kalimantan Timur dalam melakukan pengawasan dan penegakan hukum secara efektif sehingga menciptakan nilai-nilai keadilan. Nilai-nilai keadilan yang dimaksud adalah terpenuhinya hak dan kewajiban para pekerja/buruh.

Secara garis besar penulis dapat menyimpulkan bahwa hambatan yang di hadapi oleh Dinas Ketenagakerjaan dan Transmigrasi Provinsi Kalimantan Timur dalam melakukan penegakan hukum yaitu faktor sumber daya manusia yang terbatas dan anggaran dana yang tidak cukup untuk menunjang kegiatan-kegiatan formal yang dilakukan Dinas Ketenagakerjaan dan Transmigrasi Provinsi Kaltimantan Timur.

\section{E. PENUTUP}

${ }^{13}$ Dellyana Shant, Op-Cit, hlm 33. 
Kewenangan pengawasan yang tadinya berada di Kabupaten / Kota dialihkan ke pusat berdasarkan Pasal 15 ayat 1 dan 2 Undang-Undang Nomor 23 Tahun 2014 tentang Pemerintahan Daerah dalam pelaksanaanya sinergi antara Kabupaten / Kota dengan Provinsi. Pengawasan dari Pemerintah terhadap perusahaan-perusahaan dilakukan dalam kurun waktu setahun sekali akan tetapi tidak semua perusahaan dapat diawasi. Perusahaan di Provinsi Kalimantan Timur yang terdaftar hingga saat ini sebanyak kurang lebih 80.000 perusahaan kemungkinan yang bisa diawasi hanya sekitar $50 \%$ dari seluruh perusahaan yang berada di Provinsi Kalimantan Timur.Pihak Dinas Ketenagakerjaan dan Transmigrasi Provinsi Kalimantan Timur khususnya dibidang pengawasan telah melakukan pengawasan sesuai dengan standar pelayanan minimal, tetapi pada pelaksanaanya tidak bisa berjalan dengan efektif dikarenakan ditemukan beberapa kendala yaitu Sumber daya manusia yang terbatas dan anggaran dana yang tidak dapat menunjang kegiatan pengawasan dilapangan.

\section{DAFTAR PUSTAKA}

Saipul Anwar, Sendi-Sendi Hukum Administrasi Negara, Glora Madani Press, Jakarta: 2004

Zaeni Asyhadie, Hukum Kerja Hukum Ketenagakerjaan Bidang Hubungan Kerja, PT. Raja Grafindo, Jakarta: 2007

Budi Santoso, Implikasi Penerapan Standar Social Accountability 8000 Terhadap Perlindungan Keselamatan Dan Kesehatan Pekerja, Universitas Pelita Harapan Surabaya: 2012

Djumadi, Hukum Perburuhan Perjanjian Kerja, Jakarta:Rajawali Press ILO (International Labour Organization), 2013, Keselamatan dan Kesehatan Kerja ditempat Kerja, Modul 5, Jakarta: 1992

L. Husni, Hukum Ketenagakerjaan Indonesia, PT. Raja Grafindo, Jakarta: 2006

ILO, https://www.ilo.org/wcmsp5/groups/public/---asia/---ro-bangkok/---ilojakarta/documents/publication/wcms_549703.pdf/

K3, http://budayasafety.com/2013/10/artikel-tentang-keselamatan-kerja-k3.html

Abdul Khakim, Dasar-Dasar Hukum Ketenagakerjaan Indonesia, PT. Citra Aditya Bakti, Bandung: 2009

Lawrence M. Friedman, American Law An Introdution Second Edition (Hukum Amerika Sebuah Pengantar) Penerjemah Wishnu Basuki, PT. Tatanusa, Jakarta: 2001 
Mangkunegara, Manajemen Sumbar Daya Manusia Perusahaan, PT. Remaja Rosda Karya, Bandung: 2002

M. Manullang, Pokok-pokok Hukum Ketenagakerjaan di Indonesia, Rineka Cipta, Jakarta: 2001

Mondy, R. Wayne, and Robert M. Noe. Human Resource Management. Ninth Edition. Prentice Hall, USA: 2005

Abdulkadir Muhammad, Hukum dan Penelitian Hukum, PT. Citra Aditya Bakti, Bandung: 2004

Sondang P. Siagian, Manajemen Sumber Daya Manusia, PT. Bumi Aksara, Jakarta: 2008

Peraturan Menteri Tenaga Kerja Nomor 33 Tahun 2016 Tentang Tata Cara Pengawas Ketenagakerjaan

Peraturan Menteri Tenaga Kerja Nomor 5 Tahun 1996 Tentang Sistem Manajemen Keselamatan dan Kesehatan Kerja

Peraturan Pemerintah No 50 Tahun 2012 tentang Penerapan Sistem Manajemen Keselamatan dan Kesehatan Kerja

Prayudi, Hukum Administrasi Negara, Ghalia Indonesia, Jakarta: 1981

Dellyana Shant, Konsep Penegakan Hukum, Liberty, Yogyakarta: 1988

Soerjono Soekanto, Faktor-Faktor Yang Memperngaruhi Penegakan Hukum, Raja Grafindo Persada, Jakarta: 2004

Jon Soeprihanto, Manajemen Personalia, BPFE Yogyakarta, Yogyakarta; 2002

Imam Soepromo, Pengantar Hukum Perburuhan, Djambatan, Jakarta: 2005

Sri Mahmuji, Penelitian Hukum Normatif Suatu Tinjauan Singkat, Raja Grafindo Persada, Jakarta: 2007

Sugiyono, Metedologi Penelitian, Alfabeta, Bandung: 2010

Sujanto, Beberapa Pengertian di Bidang Pengawasan, Ghalia Indonesia, Jakarta: 1986

Suwarto, Undang-Undang Ketenagakerjaan Indonesia, ILO/USA Dedaration Project, Jakarta: 2003

Bambang Swasto, Manajemen Sumber Daya Manusia, UB Press, Malang: 2011

Undang-Undang Dasar Republik Indonesia Tahun 1945 
Undang-Undang Nomor 1 Tahun 1970 Tentang Keselamatan Kerja

Undang-Undang Nomor 13 Tahun 2003 Tentang Ketenagakerjaan

Wijayanti, Asti, 2009, Hukum Ketenagakerjaan Pasca Reformasi, Jakarta: PT. Sinar Grafika 